\title{
BMJ Open Who attends out-of-hours general practice appointments? Analysis of a patient cohort accessing new out-of- hours units
}

\author{
Shona, J. Kelly, ${ }^{1}$ Hilary Piercy, ${ }^{2}$ Rachel Ibbotson, ${ }^{3}$ Sally V. Fowler Davis ${ }^{4}$
}

To cite: Kelly S,J., Piercy H, Ibbotson $\mathrm{R}$, et al. Who attends out-of-hours general practice appointments? Analysis of a patient cohort accessing new out-of-hours units. BMJ Open 2018:8:e020308. doi:10.1136/ bmjopen-2017-020308

- Prepublication history for this paper is available online. To view these files, please visit the journal online (http://dx.doi org/10.1136/bmjopen-2017020308).

Received 30 0ctober 2017 Revised 11 April 2018 Accepted 13 April 2018
Check for updates

${ }^{1}$ Department of Social Work, Social Care and Community Studies, Sheffield Hallam University, Sheffield, UK ${ }^{2}$ Department of Nursing and Midwifery, Sheffield Hallam University, Sheffield, UK ${ }^{3}$ Allied Health Professions, Sheffield Hallam University, Sheffield, UK

${ }^{4}$ Sheffield Teaching Hospitals NHS Foundation Trust, Sheffield Hallam University, Sheffield, UK

Correspondence to

Professor Shona and J. Kelly; s.kelly@shu.ac.uk

\section{ABSTRACT}

Objectives This report describes the patients who used additional out-of-hours $(\mathrm{OOH})$ appointments offered through a UK scheme intended to increase patient access to primary care by extending $\mathrm{OOH}$ provision.

Design Cohort study and survey data.

Setting $\mathrm{OOH}$ appointments offered in four units in one region in England (October 2015 to November 2016). Methods Unidentifiable data on all patients were abstracted from a bespoke appointment system and the responses to a patient opinion questionnaire about this service. Descriptive analysis of the appointment data was conducted. Multivariate analysis of the opinion survey data examined the characteristics of the patients who would have gone to the emergency department (ED) had the $\mathrm{OOH}$ appointments not been available.

Results There were 24448 appointments for 19701 different patients resulting in 29629 service outcomes. Women dominated the uptake and patients from the poorest fifth of the population used nearly $40 \%$ of appointments. The patient survey found $\mathrm{OOH}$ appointments were extremely popular-93\% selecting 'extremely likely' or 'likely' to recommend the service. Multivariate analysis of patient opinion survey data on whether ED would have been an alternative to the $\mathrm{OOH}$ service found that men, young children, people of Asian heritage and the most deprived were more likely to have gone to ED without this service.

Conclusions The users of the $\mathrm{OOH}$ service were substantially different from in-hours service users with a large proportion of children under age 5 , and the poor, which support the idea that there may be unmet need as the poor have the least flexible working conditions. These results demonstrate the need for equality impact assessment in planning service improvements associated with policy implementation. It suggests that $00 \mathrm{H}$ need to take account of patients expectations about convenience of appointments and how patients use services for urgent care needs.

\section{BACKGROUND}

The increasing demands on emergency departments (EDs) in the UK has led to a policy assumption that further access to primary care will reduce demand for urgent care via EDs. ${ }^{1}$ One perceived solution is to
Strengths and limitations of this study

This evaluation reports on a complete dataset of patients attending an out-of-hours $(\mathrm{OOH})$ service over a 14-month pilot period.

- Our ability to report on the impact of providing additional $00 \mathrm{H}$ capacity on emergency department services was limited to patient opinion survey (Family and Friends (F\&F)) data.

- The F\&F survey is not a validated tool and it does not specify that responses should relate to the patient rather than the person filling out the questionnaire which limits reliability.

- The F\&F survey is very widely used and easy to complete which will have contributed to its completion rate.

- Our analysis was limited by the fact that the datasets could not be linked due to regulations around patient anonymity.

offer more out-of-hours $(\mathrm{OOH}$, evenings and weekends) primary care which is proposed as a response to the increasing demand on services from older patients with complex health conditions. ${ }^{23}$ In England, as in many other parts of the world, $\mathrm{OOH}$ healthcare provision is regarded as urgent care only ${ }^{4}$ and offered as a mixture of telephone triage, drop-in centres, EDs and triaged appointments. ${ }^{5}$ The specific value of $\mathrm{OOH}$ provision is unclear. A systematic review on the impact of primary care interventions, including $\mathrm{OOH}$ provision, on ED visits identified the lack of evidence to indicate whether it did, or did not, decrease ED visits. ${ }^{6}$ Over the past decade, National Health Service (NHS) England surveys have found a continuing decline in satisfaction with $\mathrm{OOH}$ appointments. ${ }^{78}$ There has been very little investigation on who uses $\mathrm{OOH}$ appointments.

Evaluation of recent $\mathrm{OOH}$ initiatives across Europe indicates little consistency in the demographics of those using these services. In part this may be because the limited amount 
of research is focused on a variety of outcomes such as cost, geographical accessibility and/or patient preference with few focusing on who uses $\mathrm{OOH}$ services. Keizer et al compared patients with medically necessary and unnecessary $\mathrm{OOH}$ appointments and found no differences by gender or immigration status. ${ }^{9}{ }^{10}$ More women than men used $\mathrm{OOH}$ services in Switzerland ${ }^{11}$ and in the Netherlands. ${ }^{12}$ While, an $\mathrm{OOH}$ service set-up in Glasgow was the preferred choice of men regardless of the level of urgency. ${ }^{13}$ A multivariate analysis of a service in Belgium ${ }^{14}$ found that those who opted for $\mathrm{OOH}$ appointments over ED were: women, had good self-reported health, lived in an urban environment, had high education, had no partner and were not an immigrant. ${ }^{14}$ The effect of age is particularly difficult to untangle as some studies exclude those under age $18^{1014}$ or do not recognise that attendance varies drastically across the life course as usage is greatest for the very young and old with relatively low usage during the teenage years.

There is some evidence which indicates that socioeconomic status (SES) is a contributory factor in access to primary care. People with lower SES are more likely to select ED over primary care. ${ }^{15}$ This may relate to the geographical distances between home and surgery or that people in deprived areas using more services in general. ${ }^{16}$ There is concern about access to services for the poorest segments of society ${ }^{17}$ and an NHS England policy in 2017 seeks to reduce inequalities in access to primary care ${ }^{18}$ and focuses on increasing access for socially marginalised populations such as migrants and people with mental health problems. The UK Prime Minister's Challenge Fund (first wave) was a $£ 50$ million investment, launched in 2013, to improve patient access to general practice by providing $\mathrm{OOH}$ appointments. A second wave of $£ 100$ million in funding was announced in September 2015 and supported a further 37 schemes. The Sheffield Enhanced Primary Care Programme (SEPCP) was funded as part of the second wave and involved 87 of the 90 general practitioner (GP) practices in the city. The $\mathrm{OOH}$ expansion was the largest scheme within the programme established four new satellite $\mathrm{OOH}$ clinics across the city. These clinics were intended to extend the existing $\mathrm{OOH}$ provision which consisted of a walk-in centre and a GP collaborative. New $\mathrm{OOH}$ appointments were provided via GP referral for urgent primary care Monday-Friday, 18:00-22:00 and weekends, 10:00-18:00. The units were run by practice staff from surgeries within the same area of the city and attendance was by appointment only. Patients were offered urgent $\mathrm{OOH}$ appointments via GP practices during the day or through NHS OOH telephone referral systems. The new units were not advertised.

The aim of this paper is to report on the demographic profile of attendances at the new $\mathrm{OOH}$ units during the 14-month pilot period, October 2015 to November 2016 and to offer some indication of the impact on ED.

\section{METHODS}

\section{Data sources}

Three sets of data were used in the evaluation of the $\mathrm{OOH}$ satellite clinics. The first was data for all attendances which was collected and collated from a database specifically created for the $\mathrm{OOH}$ service and supplied to the evaluation team without identifiers. The data collected consisted of: age in years, ethnicity, marital status, gender, deprivation score of home postcode ${ }^{19}$ registered practice code, core activity during the appointment (clinical advice, direct admission to secondary care, prescribed medicines, other). The GP also recorded the outcome of the appointment and selected from 13 options which were aggregated these into five ordered categories of urgency: (1) urgent-includes: 'admitted to hospital', 'ambulance arranged', 'referred to ED', 'significant event/complaint', 'needs urgent appointment with own GP', (2) managed-no follow-up includes:' prescription issued', 'no follow-up required', (3) non-urgent, needs further follow-up includes: 'call back if no better', 'needs routine appointment with own GP', 'to ring own GP if no better', 'follow-up appointment needed', (4) 'inappropriate', (5) 'did not attend'. Unfortunately marital status was missing in $67 \%$ of records and so this factor was not included in the analysis. All other variables had a high completion rate. Age categories were created to allow comparison with the other data sets. Ethnicity data were supplied under 116 different categories, most with too few patients for any subanalysis. These were reduced to six categories reflecting census categories, namely: white, mixed, Asian, black, other, not stated/missing. Home postal code was mapped by the data provider onto the deprivation score which was then categorised into national deprivation pentiles. ${ }^{19}$

The second dataset was a modified version of the self-completed Family and Friends (F\&F) patient satisfaction survey that is widely used across the NHS. At each visit, patients were asked to rate how likely they were to recommend the service to friends and family on a 5-point Likert scale from 'extremely unlikely' to 'extremely likely' as well as 'do not know'. The form was modified to also collect a question which asked 'What would you have done if you could not have attended this OOH appt.' It offered eight options: ED, waited to see own doctor, 111 (NHS telephone service), children's ED, pharmacy, walk-in centre, other (please specify) and not sure.

The third dataset was census data for all patients registered with GPs in Sheffield that was made available to the evaluation team at the start of the pilot period. This data enabled analysis of attendance rates at $\mathrm{OOH}$ clinic within the same local context of the local area served by this service.

\section{Data analysis}

On receipt of the data it was directed into the SPSS V.24. The data files were checked for completeness, and range, routing and logical checks were undertaken. Where relevant, data were also categorised and answers were grouped 
and coded for ease and clarity of analysis. All data files were then subject to statistical analysis using SPSS software and analysed to produce the descriptive statistics for the first objective. Where comparable data were available the rate per 1000 population, in that component of the population, were calculated. Rates could be calculated for gender and age group, but ethnicity was not reliably recorded and rates could not be calculated. Results are presented by deprivation pentile based on home postal code. ${ }^{19}$

Multivariate logistic regression analysis was undertaken on the F\&F data to look at the combined effect of the demographic variables. The analysis compared those who indicated that they would have gone to ED (adult or children) if they had not had the $\mathrm{OOH}$ appointment against all other alternatives. Potential explanatory variables were sex, age group, ethnicity and deprivation pentile.

The work was conducted under contract to a clinical commissioning group. As it was considered an evaluation, ethical approval was not required, however, it did conform to the information governance regulations at the time. Data were stored on a secure server that meets home office specifications for security.

\section{Patient and public involvement}

Patients were involved in the development of the overall SEPCP programme and provided feedback on the early findings during the analysis as well as participated in the final project showcase event which disseminated the findings.

\section{RESULTS}

There were 24448 appointments over the 14 months for 19701 different patients. All but $1.5 \%$ of the appointments were for patients registered with local GPs. Take-up of appointments built steadily over the 14-month period and averaged 2018 appointments per month between July and November 2016. The appointments resulted in 29629 outcomes (ie, clinical advice, prescription issued, etc). Six per cent of appointments were deemed urgent and two-thirds were non-urgent but needed follow-up. Less than $1 \%$ of appointments were judged inappropriate by the consulting GP. The non-attendance rate was $1.8 \%$ (table 1).

The patients ranged in age from newborn to 101 (see figure 1). The mean patient age was 32.04 years, however, the greatest proportion of appointments was for those under 5. At $19.0 \%$ (4634 appointments in a population of 32 922), this equates to a rate of 141 per 1000 patients under age 5 in the region (table 1 ). There were relatively few elderly or older patients at a rate of 29 per 1000 patients (table 1).

Females accounted for $60 \%$ of the total attendances. In the under 35 age group, they accounted for $70 \%$ of attendances. The patients from the poorest fifth of the population used nearly $40 \%$ of the appointments (table 1) which rose to $50 \%$ and $60 \%$ for the poorest Asian and black ethnic groups, respectively.

Non-attendance rates were of similar proportion in each deprivation pentile. The available data suggest that the service was used more by non-whites than the $15 \%$ estimated prevalence in the census data for the region. However, this must be interpreted with caution because ethnicity was not recorded for $20 \%$ of appointments.

In $66 \%$ of the appointments, it was the only time the patient used the service. Patients who attended two times accounted for another $22.2 \%$. There were only 28 people who attended 7 or more times over the 14 months. These frequent attenders were more likely to be male $(57 \%)$ and were evenly distributed across the age groups. This is not consistent with the overall age and gender pattern of the rest of the appointments. There were proportionately more people from the least deprived quintile who were frequent attenders than in the other quintiles. The small numbers limit the conclusions that can be drawn from these findings.

\section{Findings from the F\&F survey}

There were 2120 completed surveys which represents approximately $9 \%$ of attendances. Satisfaction levels were high with $93 \%$ of respondents stating that they were 'extremely likely' or 'likely' to recommend the service to F\&F if they needed similar care or treatment.

The demographics of the survey respondents were broadly similar to the $\mathrm{OOH}$ unit attendees as two-thirds of respondents were female and four-fifths were less than age 55. Postal code (used to determine deprivation) was not collected.

When asked to identify what alternative to the $\mathrm{OOH}$ unit they would have used, $30 \%$ of respondents indicated that they would have gone to ED (adult (22.2\%) or children $(7.7 \%)$ ) in the absence of the $\mathrm{OOH}$ units and only one-fifth would have waited to see their own doctor (table 2). There were no major differences in perceived alternatives to ED by gender. Those in the 16-34 age group were much more likely to identify ED and walk-in centre as an alternative. In relation to SES, those people in the worst deprivation pentile were the most likely to identify ED as their alternative (table 2). The small number of Black and Minority Ethnic patients made identifying differences by ethnicity unreliable.

Table 3 presents the results of the multivariate logistic regression analysis. Those who were more likely to see ED as an alternative to the $\mathrm{OOH}$ units were male compared with female, aged 0-15 compared with 35-64, non-white and from the most deprived quintile of the population (see table 3 ).

\section{DISCUSSION}

The $\mathrm{OOH}$ units provided 24448 additional $\mathrm{OOH}$ appointments. Uptake increased over the 14-month pilot period and non-attendance for appointments was very low. Patients using the service reported high levels of 
Table 1 Demographics of the $\mathrm{OOH}$ appointment attendances by deprivation pentile

\begin{tabular}{|c|c|c|c|c|c|c|c|c|}
\hline & \multicolumn{6}{|c|}{ IMD pentile based on home postal code†, $\mathrm{N}(\%)$} & \multirow[b]{2}{*}{ Total } & \multirow[b]{2}{*}{ Rate 000* } \\
\hline & Least & Second & Third & Fourth & Most & Missing & & \\
\hline $\begin{array}{l}\text { Total IMD } \\
\text { pentile }\end{array}$ & $\begin{array}{l}4330 \\
(17.8 \%)\end{array}$ & $\begin{array}{l}3500 \\
(14.3 \%)\end{array}$ & $\begin{array}{l}4163 \\
(17.0 \%)\end{array}$ & $\begin{array}{l}3288 \\
(13.4 \%)\end{array}$ & $\begin{array}{l}9089 \\
(37.2 \%)\end{array}$ & $\begin{array}{l}75 \\
(0.3 \%)\end{array}$ & 24448 & \\
\hline Male & $\begin{array}{l}1829 \\
(18.6 \%)\end{array}$ & $\begin{array}{l}1372 \\
(14.0 \%)\end{array}$ & $\begin{array}{l}1704 \\
(17.3 \%)\end{array}$ & $\begin{array}{l}1336 \\
(13.6 \%)\end{array}$ & $\begin{array}{l}3552 \\
(36.1 \%)\end{array}$ & $\begin{array}{l}33 \\
(0.3 \%)\end{array}$ & $\begin{array}{l}9826 \\
(40.2 \%)\end{array}$ & 33.20 \\
\hline Female & $\begin{array}{l}2500 \\
(17.1 \%)\end{array}$ & $\begin{array}{l}2128 \\
(14.6 \%)\end{array}$ & $\begin{array}{l}2459 \\
(16.8 \%)\end{array}$ & $\begin{array}{l}1952 \\
(13.4 \%)\end{array}$ & $\begin{array}{l}5537 \\
(37.9 \%)\end{array}$ & $\begin{array}{l}42 \\
(0.3 \%)\end{array}$ & $\begin{array}{l}14618 \\
(60.0 \%)\end{array}$ & 50.78 \\
\hline Missing & $\begin{array}{l}1 \\
(25.0 \%)\end{array}$ & $\begin{array}{l}0 \\
(0.0 \%)\end{array}$ & $\begin{array}{l}0 \\
(0.0 \%)\end{array}$ & $\begin{array}{l}0 \\
(0.0 \%)\end{array}$ & $\begin{array}{l}3 \\
(75.0 \%)\end{array}$ & $\begin{array}{l}0 \\
(0.0 \%)\end{array}$ & 4 & $\mathrm{~N} / \mathrm{A}$ \\
\hline \multicolumn{9}{|l|}{ Age group } \\
\hline$<1$ year & $\begin{array}{l}235 \\
(16.4 \%)\end{array}$ & $\begin{array}{l}168 \\
(11.7 \%)\end{array}$ & $\begin{array}{l}226 \\
(15.8 \%)\end{array}$ & $\begin{array}{l}183 \\
(12.8 \%)\end{array}$ & $\begin{array}{l}621 \\
(43.3 \%)\end{array}$ & $\begin{array}{l}1 \\
(0.1 \%)\end{array}$ & $\begin{array}{l}1434 \\
(5.9 \%)\end{array}$ & 249.65 \\
\hline $1.0-4.9$ & $\begin{array}{l}529 \\
(16.5 \%)\end{array}$ & $\begin{array}{l}400 \\
(12.5 \%)\end{array}$ & $\begin{array}{l}523 \\
(16.3 \%)\end{array}$ & $\begin{array}{l}394 \\
(12.3 \%)\end{array}$ & $\begin{array}{l}1352 \\
(42.3 \%)\end{array}$ & $\begin{array}{l}2 \\
(0.1 \%)\end{array}$ & $\begin{array}{l}3200 \\
(13.15)\end{array}$ & 117.74 \\
\hline $5.0-15.9$ & $\begin{array}{l}469 \\
(18.6 \%)\end{array}$ & $\begin{array}{l}357 \\
(14.1 \%)\end{array}$ & $\begin{array}{l}379 \\
(15.0 \%)\end{array}$ & $\begin{array}{l}278 \\
(11.0 \%)\end{array}$ & $\begin{array}{l}1043 \\
(41.3 \%)\end{array}$ & $\begin{array}{l}0 \\
(0.0 \%)\end{array}$ & $\begin{array}{l}2526 \\
(10.3 \%)\end{array}$ & 36.8 \\
\hline $16.0-24.9$ & $\begin{array}{l}486 \\
(15.1 \%)\end{array}$ & $\begin{array}{l}435 \\
(13.5 \%)\end{array}$ & $\begin{array}{l}541 \\
(16.8 \%)\end{array}$ & $\begin{array}{l}503 \\
(15.7 \%)\end{array}$ & $\begin{array}{l}1238 \\
(38.5 \%)\end{array}$ & $\begin{array}{l}10 \\
(0.3 \%)\end{array}$ & $\begin{array}{l}3213 \\
(13.1 \%)\end{array}$ & 34.07 \\
\hline $25.0-34.9$ & $\begin{array}{l}551 \\
(14.5 \%)\end{array}$ & $\begin{array}{l}485 \\
(12.8 \%)\end{array}$ & $\begin{array}{l}615 \\
(16.2 \%)\end{array}$ & $\begin{array}{l}541 \\
(14.2 \%)\end{array}$ & $\begin{array}{l}1588 \\
(41.8 \%)\end{array}$ & $\begin{array}{l}18 \\
(0.5 \%)\end{array}$ & $\begin{array}{l}3798 \\
(15.5 \%)\end{array}$ & 44.78 \\
\hline $35.0-59.9$ & $\begin{array}{l}1304 \\
(19.3 \%)\end{array}$ & $\begin{array}{l}1048 \\
(15.5 \%)\end{array}$ & $\begin{array}{l}1207 \\
(17.9 \%)\end{array}$ & $\begin{array}{l}896 \\
(13.3 \%)\end{array}$ & $\begin{array}{l}2270 \\
(33.6 \%)\end{array}$ & $\begin{array}{l}30 \\
(0.4 \%)\end{array}$ & $\begin{array}{l}6755 \\
(27.6 \%)\end{array}$ & 37.07 \\
\hline $60.0+$ & $\begin{array}{l}756 \\
(21.5 \%)\end{array}$ & $\begin{array}{l}607 \\
(17.2 \%)\end{array}$ & $\begin{array}{l}672 \\
(19.1 \%)\end{array}$ & $\begin{array}{l}493 \\
(14.0 \%)\end{array}$ & $\begin{array}{l}980 \\
(27.8 \%)\end{array}$ & $\begin{array}{l}14 \\
(0.4 \%)\end{array}$ & $\begin{array}{l}3522 \\
(14.5 \%)\end{array}$ & 29.21 \\
\hline \multicolumn{9}{|l|}{ Ethnicity } \\
\hline White & $\begin{array}{l}1049 \\
(16.3 \%)\end{array}$ & $\begin{array}{l}970 \\
(15.1 \%)\end{array}$ & $\begin{array}{l}1183 \\
(18.4 \%)\end{array}$ & $\begin{array}{l}801 \\
(12.5 \%)\end{array}$ & $\begin{array}{l}2403 \\
(37.4 \%)\end{array}$ & $\begin{array}{l}13 \\
(0.2 \%)\end{array}$ & $\begin{array}{l}6419 \\
(26.3 \%)\end{array}$ & * \\
\hline Asian & $\begin{array}{l}179 \\
(8.6 \%)\end{array}$ & $\begin{array}{l}83 \\
(4.0 \%)\end{array}$ & $\begin{array}{l}383 \\
(18.5 \%)\end{array}$ & $\begin{array}{l}353 \\
(17.0 \%)\end{array}$ & $\begin{array}{l}1069 \\
(51.5 \%)\end{array}$ & $\begin{array}{l}7 \\
(0.3 \%)\end{array}$ & $\begin{array}{l}2074 \\
(8.5 \%)\end{array}$ & \\
\hline Black & $\begin{array}{l}15 \\
(3.5 \%)\end{array}$ & $\begin{array}{l}17 \\
(3.9 \%)\end{array}$ & $\begin{array}{l}52 \\
(12.0 \%)\end{array}$ & $\begin{array}{l}77 \\
(17.8 \%)\end{array}$ & $\begin{array}{l}270 \\
(62.4 \%)\end{array}$ & $\begin{array}{l}2 \\
(0.5 \%)\end{array}$ & $\begin{array}{l}433 \\
(1.8 \%)\end{array}$ & \\
\hline Mixed & $\begin{array}{l}2080 \\
(19.7 \%)\end{array}$ & $\begin{array}{l}1568 \\
(14.8 \%)\end{array}$ & $\begin{array}{l}1789 \\
(16.9 \%)\end{array}$ & $\begin{array}{l}1428 \\
(13.5 \%)\end{array}$ & $\begin{array}{l}3675 \\
(34.7 \%)\end{array}$ & $\begin{array}{l}41 \\
(0.4 \%)\end{array}$ & $\begin{array}{l}10581 \\
(43.3 \%)\end{array}$ & \\
\hline Missing & $\begin{array}{l}1007 \\
(20.4 \%)\end{array}$ & $\begin{array}{l}862 \\
(17.4 \%)\end{array}$ & $\begin{array}{l}756 \\
(15.3 \%)\end{array}$ & $\begin{array}{l}629 \\
(12.7 \%)\end{array}$ & $\begin{array}{l}1675 \\
(33.9 \%)\end{array}$ & $\begin{array}{l}12 \\
(0.2 \%)\end{array}$ & $\begin{array}{l}4941 \\
(20.2 \%)\end{array}$ & \\
\hline \multicolumn{9}{|c|}{ No of attendances over the length of the evaluation } \\
\hline 1 time & $\begin{array}{l}2968 \\
(18.3 \%)\end{array}$ & $\begin{array}{l}2337 \\
(14.4 \%)\end{array}$ & $\begin{array}{l}2844 \\
(17.6 \%)\end{array}$ & $\begin{array}{l}2173 \\
(13.4 \%)\end{array}$ & $\begin{array}{l}5824 \\
(36.0 \%)\end{array}$ & $\begin{array}{l}50 \\
(0.3 \%)\end{array}$ & $\begin{array}{l}16196 \\
(66.2 \%)\end{array}$ & \\
\hline 2 times & $\begin{array}{l}948 \\
(17.4 \%)\end{array}$ & $\begin{array}{l}776 \\
(14.2 \%)\end{array}$ & $\begin{array}{l}914 \\
(16.8 \%)\end{array}$ & $\begin{array}{l}704 \\
(12.9 \%)\end{array}$ & $\begin{array}{l}2082 \\
(38.2 \%)\end{array}$ & $\begin{array}{l}22 \\
(0.4 \%)\end{array}$ & $\begin{array}{l}5446 \\
(22.2 \%)\end{array}$ & \\
\hline 3 times & $\begin{array}{l}225 \\
(13.7 \%)\end{array}$ & $\begin{array}{l}219 \\
(13.3 \%)\end{array}$ & $\begin{array}{l}282 \\
(17.2 \%)\end{array}$ & $\begin{array}{l}237 \\
(14.4 \%)\end{array}$ & $\begin{array}{l}678 \\
(41.2 \%)\end{array}$ & $\begin{array}{l}3 \\
(0.2 \%)\end{array}$ & $\begin{array}{l}1644 \\
(2.6 \%)\end{array}$ & \\
\hline $4+$ times & $\begin{array}{l}189 \\
(16.3 \%)\end{array}$ & $\begin{array}{l}168 \\
(14.5 \%)\end{array}$ & $\begin{array}{l}123 \\
(10.6 \%)\end{array}$ & $\begin{array}{l}174 \\
(15.0 \%)\end{array}$ & $\begin{array}{l}508 \\
(43.7 \%)\end{array}$ & $\begin{array}{l}0 \\
(0 \%)\end{array}$ & $\begin{array}{l}1162 \\
(4.8 \%)\end{array}$ & \\
\hline \multicolumn{9}{|l|}{ Urgency as rated by GP $\ddagger$} \\
\hline Urgent & $\begin{array}{l}266 \\
(16.6 \%)\end{array}$ & $\begin{array}{l}215 \\
(13.4 \%)\end{array}$ & $\begin{array}{l}240 \\
(14.9 \%)\end{array}$ & $\begin{array}{l}202 \\
(12.6 \%)\end{array}$ & $\begin{array}{l}675 \\
(42.0 \%)\end{array}$ & $\begin{array}{l}9 \\
(0.6 \%)\end{array}$ & $\begin{array}{l}1607 \\
(6.6 \%)\end{array}$ & \\
\hline Non-urgent needs FU & $\begin{array}{l}2681 \\
(17.5 \%)\end{array}$ & $\begin{array}{l}2172 \\
(14.2 \%)\end{array}$ & $\begin{array}{l}2580 \\
(16.8 \%)\end{array}$ & $\begin{array}{l}2048 \\
(13.4 \%)\end{array}$ & $\begin{array}{l}5792 \\
(37.8 \%)\end{array}$ & $\begin{array}{l}45 \\
(0.3 \%)\end{array}$ & $\begin{array}{l}15318 \\
(62.7 \%)\end{array}$ & \\
\hline Managed no FU & $\begin{array}{l}1276 \\
(18.6 \%)\end{array}$ & $\begin{array}{l}1029 \\
(15.0 \%)\end{array}$ & $\begin{array}{l}1243 \\
(18.1 \%)\end{array}$ & $\begin{array}{l}937 \\
(13.6 \%)\end{array}$ & $\begin{array}{l}2365 \\
(34.4 \%)\end{array}$ & $\begin{array}{l}17 \\
(0.2 \%)\end{array}$ & $\begin{array}{l}6867 \\
(28.1 \%)\end{array}$ & \\
\hline Did not attend & $\begin{array}{l}75 \\
(14.5 \%)\end{array}$ & $\begin{array}{l}59 \\
(11.4 \%)\end{array}$ & $\begin{array}{l}76 \\
(14.7 \%)\end{array}$ & $\begin{array}{l}84 \\
(16.3 \%)\end{array}$ & $\begin{array}{l}220 \\
(42.6 \%)\end{array}$ & $\begin{array}{l}2 \\
(0.4 \%)\end{array}$ & $\begin{array}{l}516 \\
(2.1 \%)\end{array}$ & \\
\hline Inappropriate & $\begin{array}{l}30 \\
(23.4 \%)\end{array}$ & $\begin{array}{l}25 \\
(19.5 \%)\end{array}$ & $\begin{array}{l}24 \\
(18.8 \%)\end{array}$ & $\begin{array}{l}15 \\
(11.7 \%)\end{array}$ & $\begin{array}{l}34 \\
(26.6 \%)\end{array}$ & $\begin{array}{l}0 \\
(0 \%)\end{array}$ & $\begin{array}{l}128 \\
(0.5 \%)\end{array}$ & \\
\hline
\end{tabular}

${ }^{*}$ Taken from a census on Sheffield CCG region as the project started-not all variables were available.

tSee Smith et al..$^{19}$

$\ddagger$ See classification of original categories in text.

CCG, clinical commissioning group; FU, follow-up; GP, general practitioner; IMD, Index of Multiple Deprivation; N/A, not applicable; $\mathrm{OOH}$, out-of-hours. 


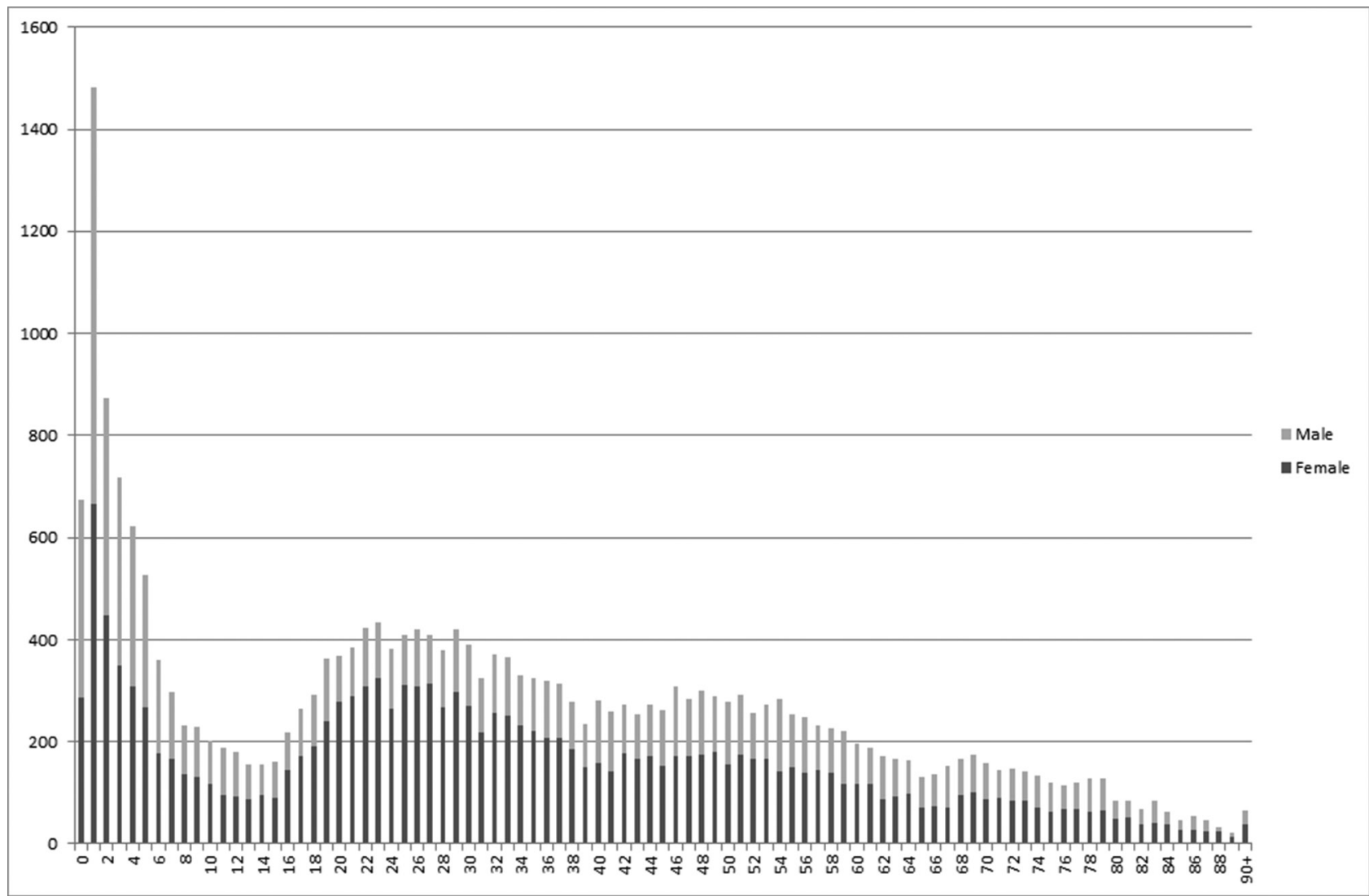

Figure 1 Distribution of attendances by gender and age.

satisfaction. The findings from the evaluation of $\mathrm{OOH}$ usage, compared with total population data, present a picture of use of this new service by younger, more deprived and predominantly female patients. The aim of the provision was to provide an alternative choice for patients who may have used ED for urgent care that could have been managed in primary care. The indications from these data are that additional capacity may have prevented some ED attendances (as per F\&F responses), however, a high proportion of attendances were not labelled urgent care but required follow-up and the $\mathrm{OOH}$

Table 2 Patient survey report of stated alternative to $\mathrm{OOH}$ service by deprivation pentile-from F\&F survey

\begin{tabular}{|c|c|c|c|c|c|c|c|}
\hline & \multicolumn{6}{|c|}{ IMD pentile†, N (\%) } & \multirow[b]{2}{*}{ Total } \\
\hline & Least & Second & Third & Fourth & Most & Missing & \\
\hline Total IMD pentile† & $\begin{array}{l}272 \\
(12.8 \%)\end{array}$ & $\begin{array}{l}270 \\
(12.7 \%)\end{array}$ & $\begin{array}{l}336 \\
(15.8 \%)\end{array}$ & $\begin{array}{l}271 \\
(12.8 \%)\end{array}$ & $\begin{array}{l}494 \\
(23.3 \%)\end{array}$ & $\begin{array}{l}477 \\
(22.5 \%)\end{array}$ & 2120 \\
\hline \multicolumn{8}{|l|}{ Alternative } \\
\hline ED $\ddagger$ & $\begin{array}{l}72 \\
(26.5 \%)\end{array}$ & $\begin{array}{l}89 \\
(33.0 \%)\end{array}$ & $\begin{array}{l}96 \\
(28.6 \%)\end{array}$ & $\begin{array}{l}69 \\
(25.5 \%)\end{array}$ & $\begin{array}{l}165 \\
(33.4 \%)\end{array}$ & $\begin{array}{l}143 \\
(30.0 \%)\end{array}$ & $\begin{array}{l}634 \\
(29.9 \%)\end{array}$ \\
\hline Walk-in centre & $\begin{array}{l}66 \\
(24.3 \%)\end{array}$ & $\begin{array}{l}64 \\
(23.7 \%)\end{array}$ & $\begin{array}{l}98 \\
(29.2 \%)\end{array}$ & $\begin{array}{l}89 \\
(32.8 \%)\end{array}$ & $\begin{array}{l}104 \\
(21.1 \%)\end{array}$ & $\begin{array}{l}115 \\
(24.1 \%)\end{array}$ & $\begin{array}{l}536 \\
(25.3 \%)\end{array}$ \\
\hline Other§ & $\begin{array}{l}44 \\
(16.2 \%)\end{array}$ & $\begin{array}{l}33 \\
(12.2 \%)\end{array}$ & $\begin{array}{l}40 \\
(11.9 \%)\end{array}$ & $\begin{array}{l}29 \\
(10.7 \%)\end{array}$ & $\begin{array}{l}64 \\
(13.0 \%)\end{array}$ & $\begin{array}{l}60 \\
(12.6 \%)\end{array}$ & $\begin{array}{l}270 \\
12.7 \%)\end{array}$ \\
\hline
\end{tabular}

†See Smith et al. ${ }^{19}$

¥Combined children's and adult ED.

§Includes a telephone $\mathrm{OOH}$ service, pharmacy and the option of 'other'.

ED, Emergency Department; F\&F, Family and Friends; GP, general practitioner; IMD, Index of Multiple Deprivation; OOH, out-of-hours. 
Table 3 Multivariate logistic regression analysis comparing those $\mathrm{OOH}$ users whose alternative was ED compared with the other alternatives*

\begin{tabular}{|c|c|c|c|}
\hline Explanatory variable & OR $^{*}$ & $P$ values & $95 \% \mathrm{Cl}$ \\
\hline \multicolumn{4}{|l|}{ Sex } \\
\hline Male & 1.24 & 0.027 & 1.02 to 1.51 \\
\hline Female & 1.00 & Ref & Ref \\
\hline Missing & 0.81 & 0.995 & 0.51 to 1.95 \\
\hline \multicolumn{4}{|l|}{ Age group } \\
\hline $0-15$ & 1.74 & $<0.001$ & 1.31 to 2.32 \\
\hline $16-24$ & 0.98 & 0.877 & 0.74 to 1.29 \\
\hline $25-34$ & 1.21 & 0.115 & 0.96 to 1.52 \\
\hline $35-64$ & 1.00 & Ref & Ref \\
\hline $65+$ & 1.37 & 0.048 & 1.00 to 1.86 \\
\hline \multicolumn{4}{|l|}{ Ethnicity } \\
\hline White & 1.00 & Ref & Ref \\
\hline Asian & 2.33 & $<0.001$ & 1.61 to 3.39 \\
\hline Black & 1.67 & 0.099 & 0.91 to 3.06 \\
\hline Mixed/other & 1.24 & 0.373 & 0.78 to 1.97 \\
\hline No response & 0.74 & 0.333 & 0.41 to 1.36 \\
\hline \multicolumn{4}{|l|}{ IMD pentile† } \\
\hline Most deprived & 1.60 & 0.001 & 1.20 to 2.14 \\
\hline 2 & 1.05 & 0.754 & 0.76 to 1.47 \\
\hline 3 & 1.00 & Ref & Ref \\
\hline 4 & 1.13 & 0.463 & 0.81 to 1.58 \\
\hline Least deprived & 1.07 & 0.699 & 0.77 to 1.49 \\
\hline Missing & 1.37 & 0.039 & 1.02 to 1.83 \\
\hline Constant & 0.46 & & 0.35 to 0.49 \\
\hline $\mathrm{N}$ & 2117 & & \\
\hline
\end{tabular}

${ }^{*}$ The OR represents the odds that a satellite unit patient will go to ED compared with a non-ED choice such as wait for the next day or a walk-in centre.

†See Smith et al..$^{19}$

ED, Emergency Department; IMD, Index of Multiple Deprivation; $\mathrm{OOH}$, out-of-hours.

service was used to increase capacity and extend access to normal GP provision.

In those under age 35, female patients accounted for the majority $(70 \%)$ of appointments for themselves and their children. Similar findings were reported from services in Switzerland ${ }^{11}$ and the Netherlands. ${ }^{12}$ But comparison with other research is difficult as those less than age 18 are often excluded (eg, Warren et al and Detollenaere et $\left.a l^{1014}\right)$. Hugenholtz et $a l^{20}$ has looked at the reasons for parents using an $\mathrm{OOH}$ cooperative in the Netherlands and found that parental apprehension about their child's health was the most important reason. Our data broadly support these findings and suggest a pattern of access to healthcare in our population over and above their routine healthcare needs. Given that women still carry the majority of childcare needs, they may have benefitted from extended access, as way of managing the health needs within the constraints of work and childcare commitments. This child care hypothesis is supported by the demographic patterns in both sets of data and by several comments on the F\&F survey where patients gave this for a reason for appreciating the $\mathrm{OOH}$ service.

The higher attendance rates among those from the more deprived pentiles may be related to both convenience/constraints and urgent need. One-third of respondents to the $\mathrm{F} \& \mathrm{~F}$ Survey reported that they would have gone to $\mathrm{ED}$ if the $\mathrm{OOH}$ unit appointment had not been available. This is similar to the one-quarter estimated in the other evaluations conducted on PMCF phase 1 programmes. ${ }^{21} 22$ Looking at all the factors together, the multivariate analysis of the F\&F survey data on whether ED would have been an alternative to the $\mathrm{OOH}$ service, found that men, young children, people of Asian origin and the most deprived were more likely to have gone to $\mathrm{ED}$ without this service. Cowling et al used the UK 2013/2014 General Practice Patient Survey to examine the relationship between work status and the convenience of opening times. Ninety-one per cent of those not in work found the times convenient while only $56 \%$ of those who could not take time off work to attend appointment found the available times convenient. Even $78 \%$ of those who could take time off also found the times convenient. However, the analysis did not stratify by deprivation and our analysis found high usage in the poorest fifth of the patients. This is the group who are those most likely to have poor working conditions and it is established that the cost of attending daytime appointments falls predominantly on poorly paid workers with employment constraints. There is widespread reporting of recent employment trends to an increase in zero-hour working contracts which provide no paid sick leave or time-off for healthcare visits. Further investigation is needed to determine if demand for primary care in these groups is being met by daytime services. ${ }^{1}$

The primary purpose of the $\mathrm{OOH}$ units was to provide urgent care through increased access to primary care. Only $6.6 \%$ of patients were labelled as urgent indicating that only a small proportion would have needed to go to ED. However, two-thirds of appointments were categorised by GPs as needing treatment and follow-up suggesting the service was used primarily to increase capacity rather than provide urgent care. This new capacity was welcomed by patient groups, but questions arise about sustainability without additional follow on funding. ${ }^{23}$ It is also important to note that there is limited consensus about what constitutes urgent care in relation to access to primary care.

There was a tiny proportion of frequent attenders in our data in contrast with other research which had a greater proportion. Our findings may be different because the $\mathrm{OOH}$ offer was not advertised. What is consistent with other findings is that our frequent attenders were mainly men in all age groups. Men are more likely to choose ED over OOH services in Belgium ${ }^{14} 15$ and to perceive 
difficulty in accessing daytime services in the UK. ${ }^{13}$ There is also some evidence that patients think it unlikely that they will get a primary care appointment and so do not try to access daytime services ${ }^{24}$ but may see evening and weekend provision as offering a new form of service.

For the broader picture of sustaining primary care, there is a need to pay attention to managing population demand. Increasing capacity in primary care with $\mathrm{OOH}$ provision should not occur without a rigorous evaluation to ensure that the service is meeting the needs of people who would otherwise have unmet need or who would have to attend ED unnecessarily. As this service was designed from the perspective of additional urgent care, an equality impact assessment was not included in the planning. This evaluation confirmed that not all patient need was urgent, but we are concerned that the demographics of attendees suggest family and employment pressures that may inhibit people-mainly younger women and families, from using daytime surgeries.

\section{CONCLUSION}

This evaluation of a new $\mathrm{OOH}$ service found heavy use by the poor and those under age 5 with a predominance of female attendees and considerable enthusiasm for the service. The significant difference in who used the $\mathrm{OOH}$ service, compared with in-hours service users raises speculation about the offer of $\mathrm{OOH}$ as a new and different form of primary care. It requires further investigation, via data linkage, to confirm that $\mathrm{OOH}$ users, access fewer in-hours services. These findings may challenge the traditional model of GP appointments and an $\mathrm{OOH}$ service expected to provide urgent care only. With capacity at an all-time low in the UK, the question of sustaining an evening and weekend service for patients to provide a level of care that ensures a future healthy, and working, population needs careful research-informed consideration.

Contributors SK was the lead on the project and responsible for meeting contract deadlines, liaising with the steering group, undertaking the data analysis and took the lead on preparing this paper. SVF-D was the lead on the qualitative component of the project and contributed to the introduction and discussion. $\mathrm{HP}$ conducted some of the interviews in the qualitative component and helped shape the paper. RI worked with the data providers, and cleaned and coded the data and wrote the methods section. All authors reviewed and discussed multiple versions of the paper. Project managers were responsible for the contracts which delineated which data should be collected and for designing the patient opinion survey.

Funding This work was supported by a contract with Primary Care Sheffield to conduct an evaluation of the Sheffield Enhanced Primary Care Programme (SEPCP). The project reported here was one component of the SEPCP evaluation.

Competing interests None declared.

Patient consent Not required.

Provenance and peer review Not commissioned; externally peer reviewed.

Data sharing statement Data used in this analysis are not in the public domain and use was covered by data sharing agreements with Primary Care Sheffield.

Open access This is an Open Access article distributed in accordance with the Creative Commons Attribution Non Commercial (CC BY-NC 4.0) license, which permits others to distribute, remix, adapt, build upon this work non-commercially, and license their derivative works on different terms, provided the original work is properly cited and the use is non-commercial. See: http://creativecommons.org/ licenses/by-nc/4.0/

(C) Article author(s) (or their employer(s) unless otherwise stated in the text of the article) 2018. All rights reserved. No commercial use is permitted unless otherwise expressly granted.

\section{REFERENCES}

1. Cowling TE, Harris M, Majeed A. Extended opening hours and patient experience of general practice in England: multilevel regression analysis of a national patient survey. BBMJ Qual Saf 2016:1-12.

2. Walker N, Baker R. Satisfaction with out of hours primary care. BMJ 2015;350:h2185.

3. England NHS. General practice: forward view. London: NHS England, 2016.

4. Jansen T, Zwaanswijk M, Hek K, et al. To what extent does sociodemographic composition of the neighbourhood explain regional differences in demand of primary out-of-hours care: a multilevel study. BMC Fam Pract 2015;16:54.

5. Mvd vanderB, Wensing M, Rvd B, et al. Towards an optimal composition of general practitioners and nurse practitioners in outof-hours primary care teams: a quasi-experimental study. BMJ Open 2017b;7:e015509.

6. Ismail SA, Gibbons DC, Gnani S. Reducing inappropriate accident and emergency department attendances: a systematic review of primary care service interventions. Br J Gen Pract 2013;63:e813-20.

7. lacobucci G. Patients are more satisfied with their own GP than with out of hours care, survey shows. BMJ 2012;345:e8512.

8. Iacobucci G. $86 \%$ of English patients are satisfied with GPs, but fewer are happy with out of hours care. BMJ 2014;349:g4448.

9. Keizer E, Smits M, Peters Y, et al. Contacts with out-of-hours primary care for nonurgent problems: patients' beliefs or deficiencies in healthcare? BMC Fam Pract 2015;16:157.

10. Warren FC, Abel G, Lyratzopoulos G, et al. Characteristics of service users and provider organisations associated with experience of out of hours general practitioner care in England: population based cross sectional postal questionnaire survey. BMJ 2015;350:h2040.

11. Huber CA, Rosemann T, Zoller M, et al. Out-of-hours demand in primary care: frequency, mode of contact and reasons for encounter in Switzerland. J Eval Clin Pract 2011;17:174-9.

12. Giesen $\mathrm{P}$, Franssen $\mathrm{E}$, Mokkink H, et al. Patients either contacting a general practice cooperative or accident and emergency department out of hours: a comparison. Emerg Med J 2006;23:731-4.

13. Drummond N, McConnachie A, O'Donnell CA, et al. Social variation in reasons for contacting general practice out-of-hours: implications for daytime service provision? Br J Gen Pract 2000;50:460-4.

14. Detollenaere J, Verlinde E, Willems S, et al. Which socio-economic factors influence patients' choice to opt for the ed or the gpc during out-of-hours: an explorative study in Flanders. Health 2014;06:1361-7

15. Willems S, Peersman W, De Maeyer P, et al. The impact of neighborhood deprivation on patients' unscheduled out-of-hours healthcare seeking behavior: a cross-sectional study. BMC Fam Pract 2013;14:136.

16. Carlisle R, Groom LM, Avery AJ, et al. Relation of out of hours activity by general practice and accident and emergency services with deprivation in Nottingham: longitudinal survey. BMJ 1998;316:520-3.

17. Buck D, Jabbal J. Tackling poverty: making more of the NHS in England. London: King's Fund, 2014.

18. NHS England. Improving access for all: reducing inequalities in access to general practice services. UK: NHS England, 2017.

19. Smith T, Noble M, Noble S, et al. The English Indices of Deprivation 2015: technical report. London: Department for communities and Local Government, 2015.

20. Hugenholtz M, Bröer C, van Daalen R. Apprehensive parents: a qualitative study of parents seeking immediate primary care for their children. British Journal of General Practice 2009;59:173-9.

21. Dolton P, Pathania V. Can increased primary care access reduce demand for emergency care? Evidence from England's 7-day GP opening. J Health Econ 2016;49:193-208.

22. Whittaker W, Anselmi L, Kristensen SR, et al. Associations between extending access to primary care and emergency department visits: a difference-in-differences analysis. PLoS Med 2016;13:e1002113.

23. Kelly S. Evaluation oif the sheffield enhanced primary care programme: final report. Sheffield, UK: Sheffield Hallam University, 2016.

24. Carret MLV, Fassa ACG, Domingues MR. Inappropriate use of emergency services: a systematic review of prevalence and associated factors. Cadernos de Saúde Pública 2009;25:7-28. 